Bogusław Pytlik

\title{
RÓŻNICE I MODYFIKACJE SPOSOBU ELEKCJI PREZYDENTA W WYBRANYCH PAŃSTWACH EUROPY ŚRODKOWEJ, WSCHODNIEJ I POKUDNIOWEJ
}

\section{Wprowadzenie}

Zasadnicza różnica dotycząca sposobu elekcji głowy państwa sprowadza się do dokonania przez ustrojodawcę wyboru między bezpośrednim a pośrednim trybem wyborów. Obydwa praktykowane są we współczesnych państwach, zaś koncentrując uwagę tylko na Europie, należy stwierdzić, iż pośrednie wybory prezydenckie są jedynie nieznacznie rzadziej stosowane niż wybory bezpośrednie. Świadczy o tym fakt, że pierwszy z wymienionych trybów znajduje zastosowanie w 13, zaś drugi w 19 państwach Europy. Przyjęcie konkretnego sposobu wyboru prezydenta nie oznaczało nigdy w państwach demokratycznych całkowitej unifikacji kolejnych czynności, których ostatecznym efektem ma być wyłonienie głowy państwa. Fakt występowania różnic $\mathrm{w}$ tej materii niewątpliwie skłania do prowadzenia studiów komparatystycznych nad prawem wyborczym. Podejmując je, należy wziąć pod uwagę nie tylko treści nowo wprowadzanych rozwiązań, ale przede wszystkim przyczyny nowelizacji odpowiednich przepisów konstytucji i ordynacji wyborczych. Przyjmując, że powody takich działań podyktowane są przede wszystkim zmieniającymi się w czasie interesami poszczególnych partii politycznych (nie zawsze są to interesy partykularne), można dojść do wniosku, iż kwestia modernizacji m.in. prawa wyborczego na urząd prezydenta pozostaje niezmiennie aktualna.

Odrębną, aczkolwiek bardzo istotną kwestią w takiej sytuacji, staje się zakres podejmowanych i ostatecznie realizowanych działań. Dokonując ich konstytucyjnoprawnej i politologicznej analizy oraz oceny, możemy uzyskać odpowiedź na pytanie, które z obowiązujących rozwiązań nie budzą wątpliwości, to jest sprawdziły się w praktyce, a które postrzegane są jako rozstrzygnięcia mniej efektywne czy też dysfunkcyjne z punktu widzenia stronnictw politycznych aktualnie sprawujących władzę. Jeszcze innym pytaniem, na które należy starać się uzyskać odpowiedź, jest to, czy prowadzona modernizacja sposobu wyboru prezydenta ma służyć tylko realizacji interesów określonych partii politycznych, czy też ma być dowodem na 
wprowadzanie coraz to efektywniejszych rozwiązań, przy jednoczesnym uwzględnianiu życzeń wyborców, zatem suwerena z woli, którego decydujący m.in. w tych kwestiach deputowani zostali powołani do stanowienia normatywnych aktów prawnych.

\section{Odmienności i zmiany w zakresie bezpośredniego trybu wyboru prezydenta}

Zgodnie z prawem wyborczym wybranych państw europejskich, w których przyjęto bezpośredni sposób wyłaniania głowy państwa, prezydent wybierany jest w wyborach powszechnych, w głosowaniu bezpośrednim, równym i tajnym. Wymienione tzw. przymiotniki wyborcze należy pojmować jako wręcz niezmienny kanon, w oparciu o który przeprowadzane są wybory. Fakt ten nie oznacza jednak, że w odpowiednich przepisach konstytucji czy też ordynacji wyborczych nie znajdziemy dodatkowych przymiotników, dzięki którym przeprowadzane głosowania można określić mianem wolnych (Rumunia, Republika Słowacka, Republika Słowenii). Bezpośredni tryb wyłaniania prezydenta nie pozostawia wątpliwości co do tego, iż przeprowadzane elekcje opierają się na zasadzie wyborów większościowych, co jest nader oczywiste, gdyż w przypadku organu jednoosobowego nie można zastosować systemu proporcjonalnego. Jak zasadnie zauważa P. Uziębło, „konsekwencją tego rozumowania jest również uznanie wyłącznie zasady równości formalnej, która odnosi się do liczby głosów posiadanej przez wyborców, nie jest bowiem możliwe zachowanie równości materialnej w wyborach większościowych"1. Stosowanie systemu proporcjonalnego mija się z celem także w przypadku wyłaniania kolegialnej głowy państwa, jak np. w Bośni i Hercegowinie, gdzie w skład prezydencji wchodzą trzej członkowie o określonej narodowości, tj. Bośniak, Serb i Chorwat. Wypada w tym miejscu zaznaczyć, że wybór tego naczelnego organu władzy państwowej przeprowadzany jest na podstawie przepisów aktu normatywnego całościowo regulującego problematykę wyborczą².

Wyraźne różnice pojawiają się zaś w przypadku zarządzania wyborów prezydenckich. Kompetencja ta powierzana jest wybranym naczelnym organom władzy państwowej lub niektórym ich podmiotom, co w praktyce oznacza, że decyzję

1 Zob. P. Uziębło, Prawo wyborcze na urząd prezydenta w Bułgarii, w: Prawo wyborcze na urzad prezydenta w państwach europejskich, red. S i R. Grabowscy, Wolters Kluwer Polska 2007, s. 55.

2 Zob. Election law of BiH, „Official Gazette of BiH”, 23/01, 7/02, 9/09, 20/02, 25/02 (Correction), 25/02, 4/04, 20/04, 25/05, 77/05, 11/06, 33/08, 37/08, za: http://www.izbori.ba/documents/ENG/Law/BH_Election_ Law.pdf (dostęp: 1 października 2011 r.). 
o zarządzeniu elekcji może podejmować izba parlamentarna na mocy własnej uchwały (Republika Bułgarii, Ukraina) lub jej przewodniczący (Republika Serbii, Republika Słowacka, Republika Serbii, Rzeczpospolita Polska), jak i kolegialny organ władzy wykonawczej (Republika Chorwacji, Rumunia). Z zupełnie innym rozwiązaniem spotykamy się w praktyce ustrojowej Bośni i Hercegowiny, gdzie obowiązek informowania wyborców o terminie głosowania, to jest o terminie zarządzenia wyborów, nałożono na Centralną Komisję Wyborczą.

$\mathrm{W}$ związku z powyższym wypada również zwrócić uwagę na odmienności dotyczące terminów, w jakich wybory prezydenckie mają być zarządzone i przeprowadzone. Jeżeli chodzi o pierwszą z wymienionych kwestii, to najdalej idące rozwiązania wprowadzono w Rzeczypospolitej Polskiej, gdzie wybory prezydenckie powinny być zarządzone nie wcześniej niż na 7 miesięcy i nie później niż na 6 miesięcy przed końcem aktualnie trwającej kadencji. Należy przypomnieć, iż w porównaniu z właściwym przepisem Małej Konstytucji z 17 października 1992 r. obydwa terminy uległy wydłużeniu o 3 miesiące ${ }^{3}$. Najkrótszy termin został zaś przewidziany przez przepisy prawa rumuńskiego, które stanowią, iż elekcja głowy państwa zarządzana jest co najmniej na 45 dni przed dniem, w którym mają się odbyć wybory. Przy określaniu tej ostatniej stosuje się dwa podstawowe rozwiązania. Pierwsze z nich, które w uproszczeniu można określić mianem „sztywnego”, obowiązuje np. w Bośni i Hercegowinie, gdzie wybory (nie tylko prezydenckie) odbywają się w pierwszą niedzielę października, lub na Ukrainie, gdzie wyboru głowy państwa dokonuje się w ostatnią niedzielę ostatniego miesiąca piątego roku kadencji. W przypadku pozostałych państw ponownie za najdalej idące rozwiązanie należy uznać to obowiązujące w Rzeczypospolitej Polskiej, zgodnie z którym wybory prezydenckie przeprowadza się nie wcześniej niż na 100 dni i nie później niż na 75 dni przed końcem aktualnie trwającej kadencji. Najkrótszy termin wprowadzony został w Republice Słowenii, gdzie elekcja głowy państwa powinna być przeprowadzona nie później niż na 15 dni przed upływem kadencji prezydenta aktualnie sprawującego swój urząd.

Zgłaszanie kandydatów na najwyższy urząd $\mathrm{w}$ państwie $\mathrm{z}$ reguły wiąże się ze spełnieniem kilku podstawowych, prawnie określonych wymogów, do których należy m.in. obowiązek składania deklaracji majątkowych (Bośnia i Hercegowina, Ukraina) lub oświadczeń lustracyjnych (Rzeczpospolita Polska, Rumunia) albo udokumentowanie poparcia dla ubiegających się o urząd prezydenta ze strony obywateli posiadających czynne prawo wyborcze do parlamentu. W przypadku ostatniego warunku różnice w liczbie wymaganych podpisów w celu skutecznego zgłoszenia

3 Zob. art. 29 ust. 7, Ustawa konstytucyjna o wzajemnych stosunkach między władza ustawodawcza i wykonawcza Rzeczypospolitej Polskiej oraz o samorządzie terytorialnym, Dz.U. z 1992 r., nr 84, poz. 426. 
kandydata są dość duże i zawierają się w przedziale od 1,5 tys. w Bośnii i Hercegowinie do 500 tys. podpisów na Ukrainie. Problem ten można także przedstawić w inny sposób, a mianowicie w odniesieniu do ogólnej liczby obywateli posiadających czynne prawo wyborcze w danym państwie. Przyjmując taki punkt widzenia, stwierdza się, iż w przypadku większości analizowanych państw zgłoszenie kandydata staje się możliwe, jeżeli poprze go od 0,15\% (Republika Serbii) do 0,34\% (Republika Słowacka) ogólnej liczby wyborców. Zdecydowanie większy poziom poparcia wymagany jest w Rumunii i na Ukrainie, gdzie wynosi on odpowiednio: $1,13 \%$ i $1,36 \%$. W przypadku tych państw można odnieść wrażenie, iż obowiązujące rozwiązania mają na celu ograniczenie liczby potencjalnych kandydatów. W odniesieniu do Rumunii wymagana liczba 200 tys. podpisów poparcia wydaje się zbyt wysoka w stosunku do ogólnej liczby obywateli tego państwa, a tym bardziej do liczby wyborców ${ }^{4}$. W przypadku zaś Ukrainy do wspomnianego wymogu dochodzi kolejny, równie ważny, mianowicie, aby nie mniej niż 200 tys. podpisów było złożonych w każdym z 2/3 regionów tego państwa ${ }^{5}$.

Mając na uwadze szeroko pojmowany proces usprawniania sposobu wyboru prezydenta $\mathrm{w}$ analizowanych państwach należy dodać, iż serbski ustawodawca zdecydował się na usunięcie z ordynacji wyborczej przepisu, z którego treści wynikało, iż kandydaci niezależni (bezpartyjni), to jest tzw. obywatelscy, mogli być skutecznie zgłaszani nawet wtedy, kiedy nie uzyskali wymaganej liczby podpisów popierających ich kandydaturę, która w przypadku tego państwa wynosi 10 tys. Rozwiązanie to można zasadnie postrzegać jako ewidentny dowód braku równego wobec prawa traktowania wszystkich kandydatów ubiegających się o najwyższy urząd w państwie. Przepis ten posiadał jeszcze jedną istotną wadę. A mianowicie: nie zawiera on informacji na temat minimalnej liczby wymaganych podpisów niezbędnych w celu dokonania rejestracji kandydatów niezależnych.

Zgromadzenie niezbędnej liczby podpisów dokumentujących poparcie wyborców dla pretendentów do urzędu głowy państwa nie zamyka problemu zgłaszania kandydatów. W niektórych z państw Europy Środkowej, Wschodniej i Południowej jest to tylko jedna z potencjalnych możliwości. Do uchwalonych tam aktów normatywnych wprowadzano także i inne przepisy mające uregulować tę kwestię

\footnotetext{
${ }^{4} \mathrm{~W}$ trakcie ostatnich przeprowadzonych w Rumuni wyborów powszechnych, tj. wyborów prezydenckich odbywających się w dniach 22 listopada i 6 grudnia 2009 r., czynnym prawem wyborczym dysponowało 18303224 obywateli tego państwa, za: http://www.electionguide.org/results.php?ID=966 (dostęp: 1 października 2011 r.). Warto także dodać, iż zgodnie z danymi z lipca 2011 r. ogólna liczba mieszkańców tego państwa wynosiła 21904551 osób, za: https://www.cia.gov/library/publications/the-world-factbook/ geos/ro.html (dostęp: 1 października 2011 r.).

${ }^{5}$ Szerzej na ten temat m.in. B. Pytlik, Prezydent Ukrainy, w: Prezydent w państwach współczesnych: modernizacja instytucji, red. J. Osiński, Oficyna Wydawnicza SGH, Warszawa 2009, s. 676.
} 
w zdecydowanie szerszy sposób. Pomijając jednostkowo występujący przepis stanowiący, iż kandydaci mogą zgłaszać się sami (Ukraina) ${ }^{6}$, akces do startu w wyborach zgłaszać mogą również deputowani do parlamentu (Republika Słowenii i Republika Słowacka) ${ }^{7}$, partie polityczne (Rumunia, Republika Słowenii) i ich koalicje (Republika Bułgarii, Republika Chorwacji, Republika Serbii, Ukraina) oraz organizacje społeczno-polityczne (Republika Serbii) czy komitety obywatelskie (np. Republika Bułgarii, Republika Chorwacji). Pozostając przy kwestii zgłaszania kandydatów przez partie polityczne, warto zwrócić uwagę na jej regulacje obowiązujące w Republice Słowenii. Zgodnie z przepisami ordynacji wyborczej kandydaci na urząd prezydenta państwa wysuwani przez stronnictwa polityczne wybierani są przez nie $\mathrm{w}$ głosowaniu tajnym i w zgodzie z procedurami przewidzianymi przez statuty tych partii. Po spełnieniu tego wymogu stosowny wniosek musi być dodatkowo opatrzony podpisami 3 deputowanych lub co najmniej 3 tys. wyborców ${ }^{8}$. Ponadto przepisy ordynacji wyborczych obowiązujących w niektórych państwach zawierają regulację ograniczającą możliwość udzielenia poparcia tylko jednemu z kandydatów (Republika Chorwacji, Rumunia, Republika Słowenii, Ukraina).

Poświęcając uwagę dwóm głównym z politycznego punktu widzenia projektom aktów normatywnych, których celem jest m.in. dalsze modernizowanie instytucji prezydenta Rzeczypospolitej Polskiej, to jest projektowi ustawy o zmianie Konstytucji RP autorstwa Klubu Parlamentarnego Platformy Obywatelskiej oraz projektowi Konstytucji Rzeczypospolitej Polskiej przygotowanemu przez Prawo i Sprawiedliwość, wypada zaznaczyć, że w obu dokumentach projektodawcy wnoszą o dokonanie zmian w zakresie regulacji normatywnych dotyczących zgłaszania kandydatów na urząd prezydenta. Ogólnie rzecz ujmując, przedstawione propozycje sprowadzają się do trzykrotnego podwyższenia aktualnie wymaganego progu poparcia. Oznacza to konieczność uzyskania co najmniej 300 tys. podpisów wyborców mających prawo wybierania do Sejmu czy też poparcia danej kandydatury przez co najmniej 0,97\% ogólnej liczby wyborców. Jeszcze inną, alternatywną propozycję zawiera projekt Prawa i Sprawiedliwości, który poza przedstawionym rozwiązaniem proponuje w art. 68 ust. 2 pkt. 1, aby kandydat na najwyższy urząd w państwie legitymował się poparciem co najmniej 300 osób pełniących funkcje publiczne pochodzące

${ }^{6}$ Za podstawę prawną takiego rozwiązania należy przyjąc przepis zawarty w art. 48 ordynacji wyborczej. Zob. Верховна Рада Украӥни; Закон від 05.03.1999 № 474-XIV, Про вибори Президента Украӥни, za: http://zakon.rada.gov.ua/cgi-bin/laws/main.cgi?nreg=474-14 (dostęp: 1 października 2011 r.).

7 W przypadku Republiki Słowenii kandydatura musi być poparta przez 10 deputowanych, zaś w przypadku Republiki Słowackiej - 15, co oznacza poparcie odpowiednio przez 12,2\% i 10\% ogólnego składu izby.

8 Zob. Art. 12, Zakon o volitvah predsednika republike, Ur.l. RS, št. 39/1992. 
z wyborów bezpośrednich oraz co najmniej 100 tys. obywateli polskich posiadających prawo wybierania ( $w$ wyborach do Sejmu - przyp. B.P.).

Podejmując problem uzasadnienia zaproponowanych rozwiązań, należy przede wszystkim zaznaczyć, że sami wnioskodawcy nie czynią tego w stopniu chociażby dostatecznym. Wprawdzie w przypadku projektu ustawy nowelizującej aktualną Konstytucje Rzeczypospolitej Polskiej jej autorzy wspominają o potrzebie wyeliminowania fikcyjności niektórych kandydatów, która powoduje zaburzenia reguł wyborczych oraz wskazują na potrzebę korzystania z doświadczeń innych państw, to - jak słusznie zauważa M. Zubik - takie „[...] uzasadnienie jest daleko niesatysfakcjonujące. W jego świetle trudno ocenić samą konieczność podwyższenia progu poparcia, jak i wybór nowego rozwiązania”. Autor stawia też zasadne pytanie, czy zwiększenie liczby popierających konkretną kandydaturę miałoby również obowiązywać w przypadku wyborów prezydenckich przeprowadzanych po opróżnieniu urzędu głowy państwa $\mathrm{z}$ racji zaistnienia przyczyn nadzwyczajnych. Nie wypada nie zgodzić się z twierdzeniem, iż utrzymanie takiego wymogu mogłoby w praktyce utrudnić rejestrację kandydata nieposiadającego dostatecznego zaplecza w postaci partii politycznej ${ }^{9}$. Niewątpliwie tak w przypadku propozycji złożonych przez Platformę Obywatelską, jak i przez Prawo i Sprawiedliwość należy uznać, iż w mniejszym lub większym stopniu ich celem jest eliminowanie części potencjalnych kandydatów zamierzających ubiegać się o najwyższy urząd w państwie.

Wprowadzanie takich rozwiązań może, a nawet powinno budzić wątpliwości z ustrojowego punktu widzenia. Ostateczne ich przyjęcie mogłoby również narazić projektodawców na niepotrzebne zarzuty sprowadzające się m.in. do tego, iż czerpią oni z doświadczeń takich państw, jak Rumunia czy Ukraina, w których pozycja ustrojowa prezydenta jest silniejsza niż ta spotykana $\mathrm{w}$ tradycyjnym modelu parlamentarno-gabinetowym czy też wynika ona z przyjętego systemu prezydencko-parlamentarnego. Wydaje się zatem, iż w takiej sytuacji niezwykle istotne jest, aby nie tylko polscy autorzy przyszłych rozwiązań konstytucyjnoprawnych nie zapominali o jakże znaczącej roli praktyki ustrojowej, ale by przede wszystkim nie dążyli do zapewnienia sobie satysfakcjonujących rozstrzygnięć już na gruncie normatywnym, przyczyniając się jednocześnie do ograniczenia możliwości wyboru, jakim ostatecznie ma dysponować elektorat.

Innym wymogiem związanym ze zgłaszaniem kandydatów mających wziąć udział $\mathrm{w}$ wyborach prezydenckich jest prawny obowiązek uiszczenia przez nich kaucji wyborczej. Rozwiązanie to jedynie w opinii ustawodawców nielicznych

\footnotetext{
9 Zob. M. Zubik, Projekt o zmianie Konstytucji RP postów KP PO (druk nr 2989, Sejm VI kadencji),
} „Przegląd Sejmowy” 2011, nr 3(104), s. 25. 
państw może mieć pozytywny wpływ na usprawnienie sposobu wyboru prezydenta. Świadczy o tym niewątpliwie fakt, iż kaucja wyborcza wymagana jest jedynie w przypadku elekcji prezydenckich przeprowadzanych w Republice Bułgarii i na Ukrainie. Warto zaznaczyć, że w przypadku obu państw w ostatniej dekadzie podjęto decyzje odnośnie do zmiany wysokości kwot wymaganej kaucji. I tak na Ukrainie kwota ta w 2009 r. wzrosła z 15 tys. do 2,5 mln hrywien. Kaucja wyborcza podlega zwrotowi tylko wówczas, gdy kandydat ubiegający się o najwyższy urząd w państwie przejdzie do drugiej tury wyborów, w przeciwnym razie złożone środki przekazywane są do budżetu państwa. Co ciekawe, przepisy ukraińskiej ordynacji wyborczej nie regulują tego problemu, w przypadku gdyby elekcja została rozstrzygnięta już w pierwszym głosowaniu. Można tylko domniemywać, iż wówczas na zwrot pieniędzy mógłby liczyć jedynie prezydent-elekt. W przypadku Republiki Bułgarii w 2001 r. zmniejszono zaś wysokość kaucji wyborczej z 250 tys. do 5 tys. lewa, a jej zwrot następuje na podstawie decyzji Centralnej Komisji Wyborczej, chyba że kandydat uzyska w trakcie wyborów mniej niż $1 \%$ ważnie oddanych głosów.

Wprowadzanie kaucji wyborczych podyktowane jest, jak się wydaje, przede wszystkim chęcią ograniczenia liczby kandydatów na urząd prezydenta. W przypadku Republiki Bułgarii niewątpliwie rozwiązanie to przyczyniło się przejściowo do osiągnięcia zamierzonego efektu. Świadczy o tym fakt, iż w wyborach przeprowadzonych 22 października 2006 r. wzięło udział jedynie 7 kandydatów (a $3 \mathrm{z}$ nich nie przekroczyło wymaganego dla zwrotu kaucji wyborczej 1\% poparcia $)^{10}$. Obecnie sytuacja wygląda inaczej. Otóż decyzję o wzięciu udziału w zaplanowanych na 23 października 2011 r. kolejnych wyborach prezydenckich podjęło ostatecznie 18 kandydatów ${ }^{11}$. Ukraina stanowi zaś przykład państwa, w którym obowiązek uiszczenia kaucji wyborczej nigdy nie miał realnego wpływu na zmniejszenie liczby kandydatów biorących udział w elekcji. Wręcz przeciwnie, do 2004 r. liczba pretendentów ubiegających się o najwyższy urząd w państwie rosła. I tak, w kolejnych latach przedstawiała się ona następująco: w $1991 \mathrm{r}$. - 6 kandydatów, w 1994 r. - 7, w 1999 r. - 13, w 2004 r. - 24 ${ }^{12}$. Do nieznacznego ograniczenia ich liczby doszło dopiero w 2010 r., kiedy to w wyborach wzięło udział 18 kandydatów ${ }^{13}$.

10 Zob. http://www.electionguide.org/results.php?ID=1057 (dostęp: 1 października 2011 r.).

11 Zob. 18 osób kandyduje $w$ wyborach prezydenckich w Butgarii, za: http://www.wiadomosci24.pl/ artykul/18_osob_kandyduje_w_wyborach_prezydenckich_w_bulgarii_212323.html (dostęp: 1 października $2011 \mathrm{r}$ ).

12 Zob. B. Pytlik, Prezydent Ukrainy, w: Prezydent w państwach współczesnych, op. cit., s. 678-682.

13 Szerzej na ten temat: B. Pytlik, Wybory prezydenckie $w$ wybranych państwach Europy Środkowej $i$ Wschodniej w latach 2009-2010, ,Rocznik Nauk Politycznych” 2011, nr 1(14), s. 31 i nast. 
Podejmując problematykę wymagań stawianych kandydatom na urząd prezydenta, należy przede wszystkim zauważyć, iż pod względem zakresu stosowanych regulacji prawnych analizowane państwa Europy Środkowej, Wschodniej i Południowej można ogólnie podzielić na dwie grupy. Pierwszą z nich tworzą państwa, które kwestie wspomnianych wymagań uregulowały w sposób mniej lub bardziej precyzyjny (Republika Bułgarii, Rumunia, Republika Słowacji, Rzeczpospolita Polska, Ukraina). Do drugiej zaliczyć zaś należy te z państw, które z racji niedoskonałości legislacyjnych, a nie nowatorskich rozwiązań w zakresie usprawniania sposobu wyboru prezydenta, odbiegają od powszechnie stosowanych w tej materii standardów. $Z$ tej przyczyny na uwagę zasługuje np. fakt, iż prawo ubiegania się o urząd głowy państwa przysługuje każdemu obywatelowi, który ukończył 18 rok życia (Republika Chorwacji) ${ }^{14}$ i legitymuje się pełnią praw publicznych (Republika Słowenii). Co ciekawe, dość lakoniczne odpowiednie serbskie przepisy prawne nie wprowadzają żadnego cenzusu wieku dla kandydatów ${ }^{15}$.

W przypadku pięciu powyżej wymienionych państw problem biernego prawa wyborczego został rozstrzygnięty w ten sposób, iż przyznano je kandydatom, którzy ukończyli 35 (Rzeczpospolita Polska ${ }^{16}$, Rumunia, Ukraina) lub 40 rok życia (Republika Bułgarii, Republika Słowacka). Warto w tym miejscu przypomnieć, że przepisy uchwalonego przez Sejm w dniu 5 stycznia 2011 r. Kodeksu wyborczego stanowią, iż biernego prawa wyborczego pozbawione są osoby, które prawomocnym wyrokiem skazano na karę pozbawienia wolności za przestępstwo umyślne ścigane z oskarżenia publicznego lub umyślne przestępstwo skarbowe (niezależnie od tego, czy wykonanie kary pozbawienia wolności zostało przez sąd warunkowo zawieszone), jak również osoby, wobec których wydano prawomocne orzeczenie sądu stwierdzające utratę prawa wybieralności ${ }^{17}$, na podstawie art. 21a ust. 2a z dnia 18 października $2006 \mathrm{r}$. o ujawnieniu informacji o dokumentach organów bezpieczeństwa państwa $\mathrm{z}$ lat 1944-1990 oraz treści tych dokumentów ${ }^{18}$. Nowe regulacje w prawie polskim dotyczące warunku niekaralności mogą, zdaniem niektórych znawców przedmiotu, budzić wątpliwości z punktu widzenia ich zgodności z Konstytucja Rzeczypospolitej Polskiej ${ }^{19}$.

${ }_{14}$ M.in. na ten temat: J. Karp, M. Grzybowski, System konstytucyjny Chorwacji, Wyd. Sejmowe, Warszawa 2007, s. 36.

${ }_{15}$ Zob. Art. 12, Zakon o volitvah predsednika republike, Ur.l. RS, št. 39/1992, op.cit.

16 Także projekt konstytucji autorstwa Prawa i Sprawiedliwości proponuje w treści art. 32 ust. 4 utrzymanie dotychczasowych rozwiązań w zakresie biernego prawa wyborczego.

17 Zob. art. $11 \S 2$ pkt. 1 i 2, ustawa z dnia 5 stycznia 2011 r., Kodeks wyborczy, Dz.U. z 2011 r. nr 21, poz. 112 - tekst ujednolicony.

18 Dz.U. z 2007 r. nr 63, poz. 425 z późn. zm.

19 Szerzej na ten temat: A. Rakowska, K. Skotnicki, Zmiany w prawie wyborczym wprowadzone przez Kodeks wyborczy, „Przegląd Sejmowy” 2011, nr 4(105), s. 16 i nast. 
$\mathrm{Z}$ zupełnie innych przyczyn na uwagę zasługują regulacje biernego prawa wyborczego obowiązującego w Bośni i Hercegowinie. Odzwierciedlają one bowiem aktualną społeczną i polityczną specyfikę tego państwa, ukształtowaną m.in. przez doświadczenia wojenne $\mathrm{z}$ lat 1992-1995. Otóż prawo to zakazuje kandydowania m.in. do prezydencji Bośni i Hercegowiny osobom, które nie opuściły nieruchomości bądź mieszkań należących do uchodźców albo będących pod opieką organu właściwego w sprawach mieszkaniowych lub ministerstwa ds. uchodźców. Zakaz kandydowania dotyczy również osób usuniętych przez wysokiego komisarza ONZ ze stanowisk publicznych w Bośni i Hercegowinie z powodu nieprzestrzegania postanowień układu $\mathrm{z}$ Dayton ${ }^{20}$. Inne stawiane $\mathrm{w}$ tym państwie kandydatom wymaganie dotyczy ich miejsca zamieszkania. W praktyce sprowadza się ono do tego, iż biernego prawa wyborczego pozbawiony jest każdy Bośniak i Chorwat zamieszkujący na stałe na obszarze Republiki Serbskiej, podobnie jak każdy Serb zamieszkujący w Federacji Muzułmańsko-Chorwackiej ${ }^{21}$.

Wybór niemalże tego samego trybu przeprowadzania elekcji prezydenta $\mathrm{w}$ przypadku wszystkich analizowanych państw niewątpliwie należy traktować jako dowód efektywności tej procedury. Ogólnie rzecz biorąc, wybory głowy państwa mogą być przeprowadzone w jednej bądź dwóch turach głosowania. Zgodnie $\mathrm{z}$ obowiązującymi regulacjami prawnymi za wybranego $\mathrm{w}$ turze pierwszej uznaje się tego $\mathrm{z}$ kandydatów, który uzyskał bezwzględną większość głosów, przy czym w przypadku Republiki Bułgarii frekwencja wyborcza musi przekroczyć 50\% wszystkich uprawnionych do głosowania. Brak ostatecznego rozstrzygnięcia wyborów w pierwszym głosowaniu (lub odnotowanie frekwencji wyborczej nieprzekraczającej 50\% - Republika Bułgarii) oznacza konieczność przeprowadzenia drugiej tury elekcji. Udział w niej bierze dwóch kandydatów, którzy w turze poprzedniej uzyskali największą liczbę ważnie oddanych głosów, zaś o ostatecznym zwycięstwie decyduje ich zwykła większość.

Termin, po upływie którego może zostać przeprowadzona druga tura głosowania, może wynosić: 7 dni (Republika Bułgarii), 14 dni (Republika Chorwacji, Republika Słowacka, Rumunia, Rzeczpospolita Polska ${ }^{22}$ ), do 15 dni (Republika Serbii) czy nie więcej niż 21 dni (Republika Słowenii). Może też być wyznaczony na trzecią niedzielę po pierwszej turze głosowania (Ukraina). Warto również dodać, że podobnie jak w przypadku wymagań stawianych kandydatom do prezydencji Bośni i Hercegowiny,

${ }^{20}$ Szerzej na ten temat: A. Frankiewicz, Prawo wyborcze do prezydencji w Bośni i Hercegowinie, w: Prawo wyborcze na urzad prezydenta w państwach europejskich..., op.cit., s. 43.

21 Ibidem, s. 47 i nast.

22 Stosowane propozycje zmian wniesione przez Platformę Obywatelską czy Prawo i Sprawiedliwość nie proponują w tej kwestii żadnych zmian. 
tak i w trakcie głosowania zasadniczą kwestią dla wyborców biorących udział w elekcji staje się miejsce ich stałego zamieszkania. A zatem głosujący w Republice Serbskiej mogą wybrać jedynie serbskiego kandydata, zaś wyborcy z Federacji Muzułmańsko-Chorwackiej mogą oddać swój głos tylko na Bośniaka lub Chorwata.

Fakt, iż przedstawiony sposób wyłaniania prezydenta jest dość powszechnie stosowany w tej części kontynentu europejskiego nie oznacza, iż z czasem nie ulegał on modyfikacjom. Podobnie jak obecnie w przypadku Republiki Bułgarii, tak również w prawie wyborczym Republiki Serbii, wchodzącej początkowo w skład Federalnej Republiki Jugosławii, a następnie Serbii i Czarnogóry, ważność wyborów prezydenckich uzależniona była od frekwencji wyborczej, która musiała przekroczyć $50 \%$. Rozwiązanie to stało się bezpośrednią przyczyną opóźnień w przeprowadzeniu wyborów prezydenckich. Począwszy od 30 grudnia 2002 r. do 11 lipca 2004 r., czyli do zakończenia kadencji prezydenta M. Milutinovicia, urząd głowy państwa pozostawał nieobsadzony, gdyż trzykrotnie przeprowadzane elekcje okazywały się nieważne z racji zbyt niskiej frekwencji wyborczej.

Doświadczenia te stały się dla serbskiego ustawodawcy wystarczającym powodem do usprawnienia sposobu wyłaniania głowy państwa. W obecnie obowiązującej ordynacji wyborczej, to jest w ustawie z 3 grudnia 2007 r. o wyborze prezydenta Republiki ${ }^{23}$, nie ma już przepisów uzależniających ważność wyborów od frekwencji wyborczej. Co ciekawe, jak również bardzo istotne z punktu widzenia skuteczności instytucji powszechnych i bezpośrednich wyborów prezydenckich, w trakcie ostatniej jak dotąd elekcji głowy państwa w Republice Serbii mającej miejsce w dniach 20 stycznia i 3 lutego $2008 \mathrm{r}$. frekwencja wyborcza w dniu pierwszej tury głosowania wyniosła $61,37 \%$, zaś podczas drugiej $-68,12 \%{ }^{24}$. Fakt ten należy traktować jako dowód aktywnego uczestnictwa Serbów w życiu politycznym swojego państwa. Na rzecz tej tezy przemawia również frekwencja wyborcza odnotowana przy okazji ostatnich wyborów parlamentarnych, przeprowadzonych 11 maja 2008 r., kiedy do urn wyborczych udało się $61,35 \%$ uprawnionych do głosowania ${ }^{25}$.

Mając na uwadze różnice w zakresie wyłaniania prezydenta obecne w analizowanych państwach, należy wyraźnie zaznaczyć fakt istnienia rozwiązania unikalnego tak dla tej części kontynentu, jak i dla całej Europy. Rozwiązanie to obowiązuje w Republice Bułgarii, a sprowadza się do tego, iż wraz z prezydentem wybierany jest wiceprezydent. Nazwiska kandydatów na obydwa urzędy umieszczane są na

${ }^{23}$ Zakon o izboru predsednika republike, za: http://www.skupstinskamreza.rs/portal/attachments (dostęp: 1 października $2011 \mathrm{r}$.).

24 Zob. http://www.electionguide.org/searchresults.php?type=1\&country=242\&search_year=any \&submitted=1\&submit. $x=48 \&$ submit.y=18 -1 października $2011 \mathrm{r}$.

${ }^{25}$ Zob. http://www.electionguide.org/results.php?ID=1403 (1 października 2011 r.) 
jednej liście wyborczej. Obaj też obligatoryjnie muszą reprezentować tę samą partię polityczną lub koalicję wyborczą ${ }^{26}$.

Problem modernizacji instytucji prezydenta rozpatrywany w kontekście usprawnienia sposobu jego wyboru musi się wiązać ze zmianami w zakresie przeprowadzania samego głosowania. Politycy sprawujący władzę często wyrażają publicznie ubolewanie z powodu zbyt niskiej frekwencji wyborczej. Równie często jednak nie podejmują żadnych działań, by tę sytuację zmienić, np. poprzez aktywizację wyborców dotkniętych przewlekłymi chorobami lub niepełnosprawnością. Pomijają także rosnącą mobilność swych obywateli, wynikającą np. z racji otwierających się nowych rynków pracy. Ów bardzo ogólnie zarysowany problem nabiera szczególnego znaczenia w czasach obecnych, charakteryzujących się ciągłym rozwojem nowych technologii, głównie informatycznych, których wykorzystanie dla celów wyborczych wydaje się wręcz oczywiste. Abstrahując od kwestii głosowania elektronicznego, które $\mathrm{z}$ prawnego punktu widzenia nie jest obecnie możliwe w żadnym $\mathrm{z}$ analizowanych państw, wypada zwrócić uwagę na inne praktykowane współcześnie rozwiązania. $\mathrm{Z}$ jednej strony być może trudno uznać je dziś za wystarczające, jednak $\mathrm{z}$ drugiej - z ubolewaniem należy odnotować fakt, iż nie stosuje ich większość państw, w których przewidziane zostały powszechne i bezpośrednie wybory prezydenckie.

W większości państw w trakcie elekcji głowy państwa wyborcy mogą oddawać swój głos osobiście. Alternatywą w takiej sytuacji jest możliwość głosowania korespondencyjnego, która przewidziana została jedynie w przepisach prawa wyborczego Bośni i Hercegowiny, a od 1 sierpnia 2011 r., to jest z chwilą wejścia w życie Kodeksu wyborczego, także w Rzeczypospolitej Polskiej. U nas jednak głosowanie korespondencyjne jest odrębnie regulowane dla wyborców niepełnosprawnych $^{27}$ oraz w obwodach głosowania utworzonych za granicą ${ }^{28}$. Warto wspomnieć, że odpowiednie przepisy tego aktu normatywnego nakładają na stosowne organy obowiązek przekazywania informacji o wyborach osobom niepełnosprawnym ${ }^{29}$ oraz zabezpieczenia tzw. nakładek Braille’a w celu umożliwienia głosowania osobom niewidomym $^{30}$. Możliwym stało się również głosowanie przez pełnomocnika ${ }^{31}$. Udzielanie pomocy głosującemu przez osobę towarzyszącą dopuszcza także rumuńskie prawo wyborcze, którego przepisy zezwalają również na dostarczenie urny wyborczej i kart do głosowania do domów i mieszkań osób chorych czy dotkniętych

26 Por. J. Karp, M. Grzybowski, System konstytucyjny Bułgarii, Wydawnictwa Sejmowe, Warszawa 2002, s. 48.

27 Zob. Art. 61a - 61j, Kodeks wyborczy (Ustawa z dnia 5 stycznia 2011 r.).

28 Zob. Art. 62 - 68, ibidem.

29 Zob. Art. 37a - 37c, ibidem.

30 Zob. Art. 40a, ibidem.

31 Zob. Art. 54 - 61, ibidem. 
inwalidztwem. Regulacje obowiązujące w Bośni i Hercegowinie, Republice Chorwackiej, Rumunii i Rzeczpospolitej Polskiej wprowadzają zaś obowiązek tworzenia lokali wyborczych dla obywateli dysponujących czynnym prawem wyborczym, a zamieszkujących w innych państwach.

Poświęcając zaś nieco uwagi kwestiom technologicznym, wypada wspomnieć, iż w Republice Bułgarii karty do głosowania zabezpieczane są odpowiednim mikrotekstem. Na oddzielną uwagę zasługuje zaś stosowany od 2006 r. w Bośni i Hercegowinie centralny elektroniczny rejestr wyborców. To z niego pobierane są, oparte na bazie danych kompletowanych przez ministerstwo spraw wewnętrznych, listy obywateli mających prawo udziału w wyborach. Przy czym każdy obywatel, który ukończył 18 rok życia jest prawnie zobowiązany do zarejestrowania się w tym systemie i uzyskania karty identyfikacyjnej.

Zagadnieniem dopełniającym szeroko pojmowaną problematykę wyboru prezydenta jest niewątpliwie kwestia czasu trwania jego kadencji. Dość powszechnie stosowanym rozwiązaniem $\mathrm{w}$ tej materii stało się przyjmowanie $\mathrm{w}$ konstytucjach analizowanych państw przepisów, których treść stanowi, iż urząd głowy państwa może być sprawowany przez 5 lat. Po wtóre, wszyscy ustrojodawcy opowiedzieli się za przyznaniem prawa do reelekcji. O ile w przypadku większości państw pięcioletni czas kadencji prezydenta był wprowadzany niemalże jednocześnie wraz z samą instytucją głowy państwa, o tyle w niektórych z nich odpowiednia decyzja $\mathrm{w}$ tej kwestii podejmowana była później. Stosownym przykładem w tym względzie jest nie tylko Rzeczpospolita Polska, gdzie do skrócenia kadencji prezydenta doszło na podstawie art. 1 ustawy z 27 września 1990 r. o zmianie Konstytucji Rzeczypospolitej Polskiej ${ }^{32}$, ale także Rumunia. Przy czym w przypadku tego ostatniego państwa decyzję o wydłużeniu kadencji z 4 do 5 lat podjęto w październiku 2003 r. Okazją do dokonania stosownej zmiany stała się nowelizacja ustawy zasadniczej. W oparciu o nią rumuński ustrojodawca podjął de facto decyzję o zaprzestaniu przeprowadzania jednoczesnych wyborów parlamentarnych i prezydenckich. Długość kadencji uległa zmianie także w przypadku prezydencji Bośni i Hercegowiny. Treść stosownych przepisów konstytucyjnych przewidywała, iż początkowo, to jest w latach 1996-1998, czas pełnienia urzędu przez pierwszych członków prezydencji będzie wynosił 2 lata, zaś następnie uległ on wydłużeniu do lat 4 .

Pewna trudność pojawia się w przypadku instytucji wiceprezydenta Republiki Bułgarskiej. A mianowicie, chodzi o problem w obliczaniu długości jego kadencji,

${ }^{32}$ Warto dodać, iż na mocy przepisu zawartego w art. 2 ust. 1 wspomnianej ustawy kadencja prezydenta Rzeczypospolitej Polskiej wybranego przez Zgromadzenie Narodowe 10 lipca 1989 r. uległa skróceniu i miała się zakończyć w chwili objęcia urzędu przez prezydenta wybranego w wyborach powszechnych. Zob. Dz.U. z 1990 r. nr 67, poz. 397. 
w przypadku gdyby objął on urząd głowy państwa na skutek przedterminowego zakończenia kadencji prezydenta. Bułgarski ustrojodawca, konstruując stosowne rozwiązania, nie zatroszczył się o odpowiednio precyzyjnie sformułowane przepisy prawne, czego skutkiem jest niemożność stwierdzenia, czy dokończenie kadencji po poprzedniku należy traktować jako pierwszą kadencję następcy, czy też nie. Zdaniem P. Uziębły literalne brzmienie stosownych przepisów ustawy zasadniczej przemawia za drugim rozwiązaniem, gdyż przepisy te stanowią, „że prezydent może być wybrany ponownie tylko jeden raz, wiceprezydent zaś kończący kadencję prezydenta nie został wybrany na ten urząd, lecz objął go w szczególnej sytuacji polityczno-prawnej”33.

\section{Problem modyfikacji i modernizacji pośredniego trybu wyboru głowy państwa}

Pośredni tryb przeprowadzania wyborów prezydenckich w Europie z pewnością nie należy do rzadkości. Fakt ten, w pełni oczywisty dla konstytucjonalistów i politologów, nie oznacza, że w każdym z odpowiednich państw przyjęte zostały te same zasady przeprowadzania elekcji. Dokonując zasadniczego podziału, możemy zatem wyróżnić te państwa europejskie, w których wyboru prezydenta dokonuje parlament $^{34}$ lub organ władzy ustawodawczej ${ }^{35}$. Pośrednie wybory prezydenckie mogą być również przeprowadzane przez specjalnie w tym celu powoływany organ, jak np. w Republice Federalnej Niemiec, z udziałem Zgromadzenia Federalnego, składającego się w połowie $\mathrm{z}$ deputowanych do Bundestagu i w połowie $\mathrm{z}$ wybieranych przez parlamenty krajowe delegatów krajów związkowych Republiki. Podobnie jest w Republice Włoskiej, gdzie spotykamy się z rozwiązaniem zwanym „systemem minimalnego powiększenia parlamentu”, polegającego na uzupełnieniu ogółu członków Izby Deputowanych i Senatu o grono delegatów specjalnie wybranych przez rady regionalne ${ }^{36}$.

33 Zob. P. Uziębło, Prawo wyborcze na urząd prezydenta w Bułgarii, w: Prawo wyborcze na urząd prezydenta w państwach europejskich, op.cit., s. 64.

34 Są to: Republika Albanii, Republika Czeska, Republika Grecka, Konfederacja Szwajcarska, Republika Łotewska, Republika Malty, Republika San Marino, Republika Turcji i Republika Węgierska.

35 Jeżeli prezydent Republiki Estońskiej nie zostanie wybrany przez parlament, to jest Riigikogu, w ciągu trzech kolejnych głosowań, wówczas jest on wyłaniany w głosowaniu przez Kolegium Wyborców, w skład którego wchodzą członkowie parlamentu oraz przedstawiciele samorządów terytorialnych. Szerzej na ten temat: J. Zieliński, Prezydent Republiki Estońskiej, w: Prezydent w państwach współczesnych: modernizacja instytucji, op.cit., s. 175 i nast.

36 Zob. I. Bokszczanin, Prezydent Republiki Włoskiej, w: Prezydent w państwach współczesnych: modernizacja instytucji, op.cit., s. 738 i n. 
Podejmując zagadnienie pośrednich wyborów prezydenckich w wybranych państwach europejskich, należy przede wszystkim zauważyć, iż nie spotykamy się aktualnie z przykładami odejścia od trybu bezpośredniego na rzecz elekcji o charakterze pośrednim. Jest wręcz odwrotnie, o czym mogą świadczyć decyzje podejmowane w przeszłości przez polskiego i słowackiego ustrojodawcę. W pierwszym przypadku ${ }^{37}$ propozycję dokonywania wyboru prezydenta w wyborach powszechnych wnoszono już w trakcie obrad Okrągłego Stołu, jednak nowelizacja konstytucji uchwalona w kwietniu 1989 r. $^{38}$ restytuowała urząd głowy państwa wybieranej przez Zgromadzenie Narodowe ${ }^{39}$. „Stało się tak głównie za sprawą strony koalicyjno-rządowej, obawiającej się wyników wyborów ${ }^{40}$. Jak podkreśla wielu komentatorów ówczesnych wydarzeń, urząd prezydenta PRL traktowano początkowo bardzo instrumentalnie - miał on czuwać nad tym, aby przemiany prawnoustrojowe nie następowały zbyt szybko i nadmiernie nie zagroziły politycznym interesom ugrupowań oddających władzę" ${ }^{41}$. Ogólnie rzecz biorąc, decyzję o przyjęciu w Rzeczypospolitej Polskiej bezpośredniego trybu wyboru głowy państwa uzasadniało się przede wszystkim: 1) wolą odejścia od kontraktu zawartego przy Okrągłym Stole, z którym bezpośrednio związana była zasada, iż elekcji dokonuje Zgromadzenie Narodowe; 2) opinią społeczeństwa wyrażoną zarówno w oświadczeniach wyborców, jak i w środkach masowego przekazu, z której wynikało, że tylko prezydent wybrany w głosowaniu powszechnym będzie miał wystarczający mandat do podejmowania decyzji ważnej dla całego narodu, 3) znaczeniem projektowanego trybu wyboru, jako elementu stabilizującego sytuację polityczną wewnątrz państwa, a także zwiększającego wiarygodność polskich przemian wobec partnerów zagranicznych ${ }^{42}$.

37 Decyzja o rozpisaniu wyborów prezydenckich w 1990 r. zapadła 21 września 1990 r. na podstawie uchwały Sejmu o skróceniu kadencji urzędującego prezydenta i wyłonieniu głowy państwa w wyborach powszechnych nie później niż do grudnia $1990 \mathrm{r}$. Warto również nadmienić, iż wraz z decyzją przyspieszającą wybory prezydenckie podjęto inną uchwałę sejmową umożliwiającą skrócenie kadencji tzw. Sejmu kontraktowego i przeprowadzenie wcześniejszych wyborów parlamentarnych. Na ten temat m.in.: B. Pytlik, Naczelne organy władzy w projektach Konstytucji III Rzeczypospolitej Polskiej: struktura i odnawianie składu, Oficyna Wydawnicza SGH, Warszawa 2005, s. 44.

38 Zgodnie z przepisami Konstytucji znowelizowanej w kwietniu 1989 r. oraz na podstawie regulaminu Zgromadzenia Narodowego z 19 lipca 1989 r., kandydatów na urząd prezydenta nie mogło być więcej niż 4. Wyboru dokonywano bezwzględną większością głosów w obecności co najmniej połowy ogólnej liczby członków Zgromadzenia Narodowego. Jeżeli takiej większości nie uzyskałby żaden z kandydatów, to z udziału w kolejnym głosowaniu odpadłby ten, na którego oddano najmniej ważnych głosów.

39 Podczas negocjacji ustalono także, wprawdzie tylko w warstwie werbalnej, że kolejne wybory głowy państwa będą już powszechne. Zob. D. Górecki, Ewolucja przepisów dotyczacych trybu wyboru prezydenta w polskim prawie konstytucyjnym, „Przegląd Sejmowy” 2006, nr 2(14), s. 15.

40 Przywracając urząd prezydenta RP, tworzono go z myślą o konkretnej osobie, ówczesnym I sekretarzu KC PZPR oraz przewodniczącym Rady Państwa. Szansę zwycięstwa dawała mu taka forma wyborów, w której przewagę głosów posiadali przedstawiciele strony koalicyjno-rządowej.

41 T. Borkowski, System rząów w nowej Konstytucji, „Państwo i Prawo” 1997, z. 11-12, s. 81.

42 Zob. B. Pytlik, Naczelne organy..., op.cit., s. 69. 
W przypadku Republiki Słowackiej zmiana trybu elekcji głowy państwa stała się możliwa dopiero po wyborach parlamentarnych z września 1998 r., kiedy to realnym stało się utworzenie nowego rządu koalicyjnego, tym razem bez udziału V. Mečiara i innych polityków populistycznych ruchów i partii politycznych. Co istotne, zmianę zasad wyboru prezydenta Republiki Słowackiej, która z prawnego punktu widzenia nastąpiła 14 stycznia 1999 r., należy postrzegać nie tylko jako rezygnację z dotychczasowej mało efektywnej procedury ${ }^{43}$, która m.in. stała się przyczyną niemożności wyboru głowy państwa, począwszy od 29 stycznia 1998 r. do 15 maja 1999 r. Można ją także odczytywać jako jeden z najistotniejszych elementów w procesie rzeczywistego demokratyzowania i stabilizowania systemu politycznego Republiki Słowackiej $^{44}$. Ujmując ten problem inaczej, można zaryzykować stwierdzenie, iż przyjęcie pośredniego trybu wyłaniania prezydenta było rozwiązaniami konstytucyjnymi nie tylko dowodem inspirowania się twórców słowackiej ustawy zasadniczej sprawdzonymi w realiach wspólnego państwa Czechów i Słowaków, ale także, a może przede wszystkim, korzystną - z politycznego punktu widzenia - koncepcją, mającą zapewnić w przyszłości V. Mečiarovi możliwość wpływania czy wręcz decydowania o wynikach wyborów prezydenckich.

Pośredni tryb wyboru prezydenta w wybranych państwach Europy Środkowej, Wschodniej i Południowej jest aktualnie praktykowany w Republice Czeskiej i Węgierskiej, gdzie został on utrzymany przez przepisy konstytucji uchwalonej 18 kwietnia 2011 r. Przypadki obu państw niewątpliwie zasługują na uwagę, chociaż z zupełnie innych powodów. Republika Czeska jest przykładem państwa, w którym problematyka zmiany trybu elekcji głowy państwa, to jest wprowadzenia powszechnych i bezpośrednich wyborów prezydenckich, jest rozważana już od 1998 r. Republika Węgierska, czy też zgodnie z obowiązującą od 1 stycznia 2012 r. nową nazwą państwa - Węgry, dzięki uchwaleniu nowej ustawy zasadniczej, zasługują na niemniejszą uwagę. Analiza odpowiednich przepisów nowej konstytucji pozwala na udzielenie odpowiedzi na pytanie, czy i w jakim stopniu usprawnią one sposób wyboru prezydenta.

Zanim zasygnalizowane kwestie staną się przedmiotem odrębnych rozważań, należy poświęcić nieco uwagi zasadniczym rozwiązaniom, w oparciu o które dokonuje się wyboru głowy państwa w Republice Czeskiej i Republice Węgierskiej, podobnie będzie się czynić na Węgrzech. Zarządzanie wyborów prezydenckich jest kompetencją przyznaną w obu państwach przewodniczącym izb parlamentarnych.

\footnotetext{
${ }^{43}$ Brak efektywności sprowadzał się przede wszystkim do tego, iż w każdej turze wyborów obowiązywał wymóg uzyskania większości 3/5 głosów.

44 Szerzej na ten temat: B. Pytlik, Prezydent Republiki Słowackiej, w: Prezydent w państwach współczesnych..., op.cit., s. 624 i nast.
} 
W Republice Czeskiej jednak elekcję zarządza przewodniczący izby pierwszej, czyli Izby Poselskiej, zaś w przypadku Republiki Węgierskiej/Węgier przewodniczący unikameralnego organu władzy ustawodawczej, to jest Zgromadzenia Krajowego. Wybory prezydenta muszą odbyć się w ciągu ostatnich 30 dni kadencji urzędującej głowy państwa (Republika Czeska) lub nie wcześniej niż 60 dni, a nie później niż 30 dni przed jej zakończeniem (Węgry) ${ }^{45}$.

Za dość osobliwą należy uznać obowiązującą w Republice Czeskiej procedurę zgłaszania kandydatów na urząd prezydenta. Jak pokazuje to praktyka, pośredni tryb wyboru głowy państwa nie eliminuje możliwości proponowania kandydatur przez podmioty niebędące członkami którejś z izb parlamentu, chociaż treść właściwego przepisu konstytucji ${ }^{46}$ stanowi, iż prawem zgłaszania kandydatów dysponuje wyłącznie grupa co najmniej 10 posłów lub 10 senatorów, co oznacza, iż nie mogą tego czynić wspólnie. Natomiast nie jest wymagane, aby grupę zgłaszających tworzyli posłowie czy senatorowie reprezentujący jedną partię polityczną. Podobnie jak dotychczas, kandydaci na urząd prezydenta Węgier będą zgłaszani jedynie przez deputowanych. Jednak i w tej materii zaszła dość istotna różnica. Otóż pod rządami poprzedniej konstytucji dla ważności zgłoszonej kandydatury wymagana była pisemna zgoda co najmniej 50 członków Zgromadzenia Krajowego. Sytuacja ta zmieni się wraz z wejściem w życie nowej ustawy zasadniczej. W praktyce oznacza to podniesienie wymaganego progu poparcia. Zgodnie $\mathrm{z}$ art. 11 ust. 2 nowo uchwalonej konstytucji ${ }^{47}$ każda kandydatura będzie musiała być poparta przez co najmniej 1/5 członków Zgromadzenia Krajowego, to jest w rzeczywistości przez co najmniej 78 deputowanych. Dążąc do ograniczenia liczby zgłaszanych kandydatur, ustrojodawca nie tylko wprowadził przedstawioną zmianę, ale również utrzymał w mocy przepis obowiązujący w poprzedniej ustawie zasadniczej, którego treść stanowi, iż każdy deputowany może udzielić poparcia tylko jednemu kandydatowi ubiegającemu się o urząd prezydenta.

Spełnienie wymagań stawianych kandydatom na urząd prezydenta związane jest w przypadku Republiki Czeskiej przede wszystkim z dysponowaniem biernym prawem wyborczym w wyborach do Senatu. $Z$ treści dość ogólnie sformułowanego przepisu art. 57 ust. 1 konstytucji wynika, iż ubiegający się o urząd głowy państwa musi być obywatelem Republiki Czeskiej, który ukończył 40 rok życia i dysponuje pełną zdolnością do czynności prawnych. Czynnikiem o zasadniczym znaczeniu jest wykluczenie przeszkody w postaci biernego prawa wyborczego (ineligibility)

\footnotetext{
${ }^{45}$ Rozwiązanie to zastąpi inne, zgodnie z którym wybory musiały się odbyć co najmniej na 30 dni przed końcem aktualnej kadencji prezydenta.

46 Zob. Art. 58 ust. 1, w: Konstytucja Republiki Czeskiej, przeł. M. Kruk, Wyd. Sejmowe, Warszawa 1994.

47 Zob. Magyar Közlöny z 25 kwietnia 2011 r. Nr 43, s. 10656.
} 
$\mathrm{z}$ racji osądzenia za zdradę stanu bądź z powodu dwukrotnego pełnienia w przeszłości urzędu głowy państwa ${ }^{48}$. Nie wprowadzono zaś żadnych zmian w nowej węgierskiej ustawie zasadniczej, co oznacza, iż prezydentem może zostać każdy mieszkaniec, który posiada obywatelstwo węgierskie i ukończył 35 rok życia. Jak widać, obowiązujące w obu państwach rozwiązania dotyczące biernego prawa wyborczego kandydatów na urząd prezydenta pokrywają się z tymi stosowanymi w państwach, gdzie elekcja ma charakter bezpośredni.

Tryb przeprowadzania wyborów prezydenckich $\mathrm{w}$ obu państwach przewiduje możliwość oddawania głosów w jednej lub dwóch (Węgry), a nawet w trzech turach głosowania (Republika Czeska). Porównując obie procedury, należy stwierdzić, iż ta, która ma dopiero wejść w życie na Węgrzech, jest mniej skomplikowana, także w porównaniu z poprzednio obowiązującą. Węgierski ustrojodawca uprościł przeprowadzanie elekcji, wprowadzając rozwiązanie zapewniające skuteczny wybór głowy państwa najpóźniej w drugim głosowaniu. Podobnie jak wcześniej, tak i w przyszłości na urząd prezydenta w pierwszej turze głosowania będzie wybrany ten $\mathrm{z}$ kandydatów, który uzyska co najmniej kwalifikowaną większość 2/3 głosów członków Zgromadzenia Krajowego. Gdyby wyniki pierwszego głosowania nie przyniosły ostatecznego rozstrzygnięcia, wówczas zarządzona zostanie tura druga, w której weźmie udział dwóch kandydatów, którzy w poprzednim głosowaniu uzyskali największą liczbę ważnie oddanych głosów. Tym razem o wyborze zdecyduje zwykła większość ważnie oddanych głosów. Zgodnie z przepisem art. 11 ust. 5 nowej węgierskiej konstytucji procedura głosowania powinna być zakończona najpóźniej w ciągu 2 kolejnych dni, co oznacza, iż czas przeznaczony na skuteczny wybór prezydenta został skrócony o dzień.

W porównaniu z zasadami wyborczymi na Węgrzech, wybory przeprowadzane przez czeski parlament mogą okazać się bardziej czasochłonne. Wynika to z faktu, iż w pierwszej turze głosowania wybrany zostaje ten z kandydatów, za którym opowiedziała się ponad połowa posłów i więcej niż $50 \%$ senatorów. W przypadku nieuzyskania wymaganej większości głosów przez żadnego z pretendentów w ciągu 14 dni przeprowadzana jest druga tura, w której bierze udział dwóch kandydatów ten, który uzyskał największą liczbę głosów w Izbie Poselskiej, i ten, na którego głosowała większość senatorów. Gdyby kandydaci biorący udział w elekcji uzyskali taką samą liczbę głosów w Izbie Poselskiej lub w Senacie, wówczas sumuje się głosy oddane na nich w obu izbach w pierwszej turze głosowania, a do następnej przechodzi ten, za którym opowiedziała się największa liczba głosujących posłów i senatorów. W drugiej turze głosowania na urząd prezydenta Republiki Czeskiej wybrany zostaje ten

${ }^{48}$ Zob. Art. 65 ust. 2, w: Konstytucja Republiki Czeskiej..., op.cit. 
z kandydatów, który uzyskał większość głosów członków Izby Poselskiej i Senatu. $\mathrm{W}$ razie gdyby i ta procedura nie przyniosła ostatecznego rozstrzygnięcia, wówczas po upływie 14 dni przeprowadzana jest trzecia tura elekcji, w której uczestniczą ci kandydaci, którzy brali udział w turze drugiej. W ostatnim głosowaniu nie liczy się już oddzielnie głosów oddanych przez posłów i senatorów. Fakt ten oznacza, że zwycięzcą elekcji zostaje kandydat, który uzyskał zwykłą większość głosów biorących udział w głosowaniu deputowanych. Niewyłonienie głowy państwa w trakcie trzeciej tury głosowania jest równoznaczne z koniecznością zarządzenia nowych wyborów ${ }^{49}$. Warto również dodać, że warunkiem ważności głosowania jest odpowiednie quorum wynoszące co najmniej 1/3 ogólnej liczby posłów i taką samą liczbę senatorów.

Tryb wyboru prezydenta Republiki Czeskiej na przestrzeni ostatnich dwudziestu lat nie ulegał zbyt wielu modyfikacjom. Zmiany, jakie tu zachodziły, wiązały się z możliwością przeprowadzenia głosowania jawnego w przypadku zgłoszenia tylko jednego kandydata. Bezpośrednią i polityczną przyczyną wprowadzenia w 1989 r. tego rozwiązania był brak pewności co do wyboru V. Havla. Kolejna zmiana wdrożona w 1992 r. polegała na odstąpieniu od wymogu poparcia któregoś z kandydatów przez co najmniej 3/5 głosujących. Ta dość duża kwalifikowana większość głosów okazała się w przeszłości, to jest w 1992 r., przeszkodą skutecznie uniemożliwiającą wybór głowy państwa w sumie w pięciu kolejno podejmowanych próbach wyłonienia prezydenta ${ }^{50}$.

Poświęcając nieco więcej uwagi zasadzie tajności wyborów, należy nadmienić, iż w przypadku Republiki Węgierskiej (podobnie będzie pod rządami nowej konstytucji) jej obowiązywanie jest obligatoryjne. W Republice Czeskiej zasada ta może być stosowana fakultatywnie. Jak pokazuje praktyka, w przypadku elekcji prezydenckich przeprowadzanych w latach 1998, 2003 i 2008 Izba Poselska i Senat podejmowały uchwały o przeprowadzeniu elekcji w głosowaniu tajnym.

Kadencja prezydenta Republiki Czeskiej trwa 5 lat, licząc od dnia złożenia ślubowania. Na podstawie przepisu art. 57 ust. 2 czeskiej konstytucji, stanowiącego, iż „nikt nie może być wybrany więcej niż dwa razy z rzędu” można dojść do istotnego wniosku. A mianowicie, iż były prezydent, nawet jeżeli pełnił już dwukrotnie najwyższy urząd w państwie, może ponownie ubiegać się o prezydenturę. Oczywiście pod warunkiem, iż po tym, jak sprawował urząd prezydenta, nastąpiła przerwa wynosząca co najmniej jedną kadencję. Czas trwania kadencji głowy państwa $\mathrm{z}$ woli węgierskiego ustrojodawcy niezmiennie wynosi 5 lat. Począwszy od dnia restytuowania

49 Zob. Art. 58 ust. 2, 3, 4, 5, 6, 7, 8, w: Konstytucja Republiki Czeskiej..., op.cit.

50 Por. J. Filip, Prawo wyborcze na urząd prezydenta w Czechach, w: Prawo wyborcze..., op.cit., s. 219. 
instytucji prezydenta, to jest od 18 października 1989 r. ${ }^{51}$ do chwili obecnej, nigdy nie kwestionowano faktu, iż prezydentowi może przysługiwać prawo tylko do jednej reelekcji, co w tekście nowo uchwalonej konstytucji potwierdza przepis art. 10 ust. 3.

Jak już zauważono, problem bezpośrednich wyborów prezydenckich w Republice Czeskiej jest przedmiotem rozważań od kilkunastu lat. Istotne wątpliwości co do ciągle aktualnego trybu elekcji głowy państwa pojawiły się już w 2003 r., kiedy to wybrany został następca V. Havla, to jest V. Klaus. Wybory przeprowadzone 15 i 24 stycznia 2003 r. były niewątpliwym potwierdzeniem poważnego kryzysu politycznego, który dotknął partie tworzące ówczesny rząd koalicyjny. To właśnie dzięki zaistniałemu stanowi rzeczy możliwym stał się wybór na urząd prezydenta kandydata, który oficjalnie nie posiadał poparcia większości posłów i senatorów ${ }^{52}$. Na skutek upolitycznienia wyborów prezydenckich stały się one de facto przedmiotem rozgrywek partyjnych prowadzonych w celu realizacji partykularnych interesów. Z punktu widzenia stronnictw politycznych, reprezentowanych w obu izbach czeskiego parlamentu, korzystnym okazało się odrzucenie przez Izbę Poselską dwóch projektów ustaw o bezpośrednim wyborze prezydenta ${ }^{53}$. Potrzebę dokonania zmiany trybu wyboru głowy państwa dostrzegano powszechnie także przed następną elekcją, przeprowadzoną 8, 9 i 15 lutego 2008 r. Warto nadmienić, iż wówczas za wprowadzeniem bezpośrednich wyborów prezydenckich opowiadał się przede wszystkim główny kontrkandydat V. Klausa, to jest J. Švejnar, popierany przez Czeską Partię Socjaldemokratyczną, Partię Zielonych, Komitet Wyborczy Zjednoczenie List Niezależnych, Komitet Wyborczy Otwarci Demokraci, a także przez V. Havla. Dążenie do postawionego sobie przez Klausa celu, jakim było powtórne objęcie urzędu prezydenta Republiki Czeskiej, skutecznie eliminowało możliwość dokonania jakichkolwiek zmian w zakresie obowiązującego prawa wyborczego.

Fakt, iż V. Klaus nie będzie mógł po raz trzeci z rzędu objąć w 2013 r. najwyższego urzędu w państwie, jak również wyniki wyborów parlamentarnych przeprowadzonych 28 i 29 maja 2010 r. spowodowały, że problem modernizacji prawa wyborczego na urząd prezydenta znów stał się aktualny. Sprawująca od 12 lipca 2010 r. rządy centroprawicowa koalicja ${ }^{54}$ jeszcze we wrześniu tego samego roku zapowiedziała, iż zamierza przeprowadzić nowelizację konstytucji, obejmującą wprowadzenie bez-

51 Tego dnia dokonano nowelizacji konstytucji, m.in. wprowadzając w miejsce Rady Prezydialnej urząd prezydenta państwa. Szerzej na ten temat m.in.: B. Pytlik, Prezydent Republiki Wegierskiej, w: Prezydent w państwach..., op.cit., s. 708 i nast.

52 Zob. R. Morawiec, Wybory prezydenckie w Republice Czeskiej - konsekwencje dla czeskiej polityki zagranicznej, „Biuletyn PISM” 2003, nr 12(116), s. 755.

${ }^{53}$ Autorami projektów aktów normatywnych były Unia Wolności i Obywatelska Partia Demokratyczna.

54 W jej skład wchodzą następujące partie: Obywatelska Partia Demokratyczna, Tradycja Odpowiedzialność Prosperita 09 (tzw. TOP 09) i Sprawy Publiczne. 
pośrednich wyborów prezydenckich oraz dokonanie zmian przepisów regulujących sprawowanie mandatu poselskiego i zakresu kompetencji Najwyższego Urzędu Kontroli. Rząd przewodniczącego P. Nečasa wywiązał się z podjętego zobowiązania w dniu 29 czerwca 2011 r., kiedy to do Izby Poselskiej wpłynął projekt ustawy nowelizującej czeską konstytucję ${ }^{55}$. Analizując problem bezpośrednich wyborów prezydenckich z perspektywy aktualnej sytuacji politycznej w Republice Czeskiej, należy stwierdzić, iż o ile idea wprowadzenia takiego trybu elekcji teoretycznie popierana jest tak przez partie koalicji rządowej, jak i większość stronnictw opozycyjnych, o tyle rozbieżności dotyczące zakresu uprawnień i odpowiedzialności głowy państwa mogą doprowadzić do nieuchwalenia stosownej nowelizacji. Zdaniem niektórych polityków Obywatelskiej Partii Demokratycznej zmiana trybu elekcji głowy państwa jest mało prawdopodobna także ze względu na obecny układ sił w obu izbach parlamentu. Biorąc pod uwagę fakt, iż Czeska Partia Socjaldemokratyczna dysponuje największą liczbą mandatów w Izbie Poselskiej i Senacie, nie można wykluczyć, iż jej deputowani, dążąc do realizacji własnych interesów, to jest doprowadzenia do objęcia urzędu prezydenta Republiki Czeskiej przez polityka tej partii, będą głosować przeciwko nowelizacji ustawy zasadniczej. Większych szans na wprowadzenie bezpośrednich wyborów prezydenckich nie dają również politycy opozycyjnej Partii Praw Obywateli. Ich zdaniem aktualnie prowadzone w parlamencie prace są tylko pozorną dyskusją na ten temat i mało realnym jest, aby doszło do stosownych zmian przed najbliższymi wyborami prezydenckimi, które powinny się odbyć w lutym $2013 \mathrm{r}$. A zatem nie można wykluczyć, iż w przypadku Republiki Czeskiej, optymalny z punktu widzenia realizacji interesów politycznych, tryb wyłaniania głowy państwa obowiązuje od dawna i nie ma żadnego znaczenia, iż spełnia on tylko i wyłącznie oczekiwania samych polityków, którzy jedynie stwarzają pozory, iż są gotowi uwzględnić żądania obywateli państwa w omawianej materii ${ }^{56}$.

Koncentrując uwagę na propozycjach zmian odpowiednich przepisów zawartych w rządowym projekcie ustawy nowelizującej Konstytucję Republiki Czeskiej, który teoretycznie miałby wejść w życie z dniem 1 października 2012 r., należy zauważyć, iż przyszłe wybory prezydenckie miałyby odbywać się w głosowaniu tajnym, na podstawie powszechnego, równego i bezpośredniego prawa wyborczego. Zwycięzcą elekcji miałby zostać ten z kandydatów, który w pierwszej turze głosowania

${ }_{55}$ Zob. Vládní návrh na vydání zákona kterým se mění ústavní zákon č. 1/1993 Sb., Ústava České republiky, ve znění pozdèjších ústavních zákonu, Sněmovní tisk 415.

${ }^{56} \mathrm{Na}$ początku października $2011 \mathrm{r}$. dobiegła końca akcja zbierania podpisów pod petycją w sprawie wprowadzenia bezpośrednich wyborów prezydenckich. Inicjatorem przedsięwzięcia była Partia Praw Obywateli, a petycję poparło 100 tys. Czechów. Należy nadmienić, iż sygnatariusze petycji domagają się również stosowania takiego trybu elekcji w celu wyłaniania prezydentów miast i starostów. Zob. Czechy petycja - wybory prezydenckie, za: http://stooq.hu/n/?f=519334 (dostęp: 4 października 2011 r.). 
uzyskałby poparcie bezwzględnej większości głosujących wyborców. W przypadku gdyby pierwsze głosowanie nie doprowadziło do ostatecznego rozstrzygnięcia elekcji, wówczas po upływie 14 dni miałaby odbyć się druga tura głosowania. Brałoby w niej udział tylko dwóch kandydatów, którzy dwa tygodnie wcześniej uzyskali największe poparcie ze wszystkich kandydujących. Jeżeli zaś dwaj pierwsi uzyskaliby taką samą liczbę głosów, to poza nimi w drugiej turze wyborów wziąłby udział również kandydat (ewentualnie kandydaci), który otrzymał drugą co do wielkości liczbę ważnie oddanych głosów. W wyniku drugiej tury głosowania na urząd prezydenta Republiki Czeskiej wybranym byłby ten z kandydatów, który zostałby poparty przez największą liczbę wyborców oddających ważne głosy. W przypadku gdyby i na tym etapie elekcji ubiegający się o najwyższy urząd w państwie zostali poparci przez taką samą liczbę głosujących, wówczas wybory uznaje się za nierozstrzygnięte, a wciągu najbliższych 10 dni musi zostać wyznaczony ich następny termin ${ }^{57}$.

Przedstawiony potencjalny sposób wyboru prezydenta Republiki Czeskiej, ogólnie rzecz biorąc, należy uznać za powtórzenie trybu powszechnie stosowanego w przypadku innych analizowanych państw, gdzie wybory bezpośrednie są praktykowane. Fakt ten jednak nie oznacza, iż czeski rząd, przygotowując projekt odpowiedniego aktu normatywnego, nie zaproponował i innych, oryginalnych dla czeskiego prawa konstytucyjnego rozwiązań. Niewątpliwie na uwagę zasługuje fakt, iż biernym prawem wyborczym $\mathrm{w}$ wyborach prezydenckich miałby dysponować każdy obywatel państwa, który ukończył 18 rok życia, a jego kandydatura zostałaby poparta przez co najmniej 50 tys. wyborców dysponujących czynnym prawem wyborczym. Ponadto w projekcie nowelizacji utrzymano przepis umożliwiający zgłaszanie kandydatur przez posłów i senatorów. O ile nie uległa zmianie liczba senatorów, których poparcie jest niezbędne dla skutecznego zgłoszenia kandydata (10), o tyle zaproponowano zwiększenie liczby posłów z 10 do 20 . Zarządzanie wyborów prezydenckich miałoby stać się kompetencją przewodniczącego izby drugiej parlamentu, a w przypadku gdyby funkcja przewodniczącego Senatu pozostawała nieobsadzona, wówczas przypadałaby przewodniczącemu Izby Poselskiej. Przewodniczący pierwszej bądź drugiej izby czeskiego parlamentu byłby zobowiązany do zarządzenia elekcji najpóźniej na 90 dni przed końcem aktualnie trwającej kadencji głowy państwa. Samo głosowanie zaś powinno się odbyć w terminie od 60 do 30 dni przed jej zakończeniem ${ }^{58}$. Autorzy projektu ustawy nowelizującej konstytucję podjęli decyzje, iż wszystkie pozostałe

57 Zob. Art. 1 ust. 2, Vládní návrh na vydání zákona kterým se mèní ústavní zákon č. 1/1993 Sb., Ústava České republiky, ve zněni pozdèjších ústavních zákonů, Sněmovní tisk 415, op.cit.

58 Zob. ibidem. 
kwestie związane z realizacją prawa wyborczego na urząd prezydenta zostaną zawarte w przyszłej ordynacji wyborczej ${ }^{59}$.

Analizując tryb wyboru głowy państwa zawarty w mającej niebawem obowiązywać Konstytucji Węgier, należy zauważyć, iż niewielkie jego zmiany niewątpliwie świadczą o tym, że zarówno dotychczasowy, jak i ten nieco zmodernizowany sposób elekcji zostały pozytywnie ocenione przez premiera V. Orbána. Oznacza to, iż wpisują się one w jego wizję funkcjonowania naczelnych organów władzy państwowej. Za interesujący należy jednak uznać fakt, iż ustrojodawca, znosząc dotychczasowy konstytucyjny obowiązek uzależniający korzystanie z praw wyborczych od stałego zamieszkania na terytorium państwa, nie zdecydował się na wprowadzenie powszechnych i bezpośrednich wyborów prezydenckich. Jak widać, deklarowane przez premiera dążenie do silniejszego związania z ojczyzną Węgrów mieszkających poza granicami państwa nie musi mieć żadnego związku z możliwością ich udziału w wyłanianiu głowy państwa. $Z$ drugiej strony można zasadnie przyjąć, iż jedynie nieznaczne zwiększenie zakresu uprawnień prezydenta nie stanowiło wystarczającej podstawy do wprowadzenia nowego sposobu przeprowadzania elekcji prezydenckich. Poszukując uzasadnienia dla utrzymania status quo w analizowanej materii, można też dodać, iż za utrzymaniem dotychczasowych rozwiązań na pewno przemawiały argumenty natury finansowej. Chociaż z drugiej strony rodzi się pytanie, czy powstałe w ten sposób oszczędności w wystarczający sposób uzasadniają pomijanie decyzji Węgrów w tej sprawie. Abstrahując od próby rozstrzygnięcia tej kwestii, należy wyraźnie zaznaczyć, iż właśnie sposób, w jaki pracowano nad projektem, a następnie uchwalano Konstytucję Węgier, bardzo wyraźnie pokazuje stopień dbałości obecnej węgierskiej koalicji rządowej o zapewnienie jak najszerszej legitymizacji dla fundamentalnego dla ustroju państwa aktu normatywnego. W tym miejscu warto dodać, iż twórcy konstytucji przeprowadzili „konsultacje społeczne”, których wyniki przedstawili parlamentowi zaledwie dwa tygodnie po terminie przeznaczonym na udzielenie odpowiedzi, co zdaniem polityków opozycyjnych praktycznie uniemożliwiało uwzględnienie odpowiedzi zawartych w rozesłanych wcześniej ankietach, w których zabrakło też pytań dotyczących najbardziej kontrowersyjnych zmian ustrojowych. Niezwykle istotny jest również fakt, iż twórcy projektu konstytucji całkowicie zignorowali żądania opozycji, domagającej się przeprowadzenia referendum w sprawie przyjęcia nowej ustawy zasadniczej ${ }^{60}$. Tryb, w jakim została przygotowana

59 Zob. Art. 1 ust. 3, ibidem.

60 Szerzej na ten temat: A. Sadecki, M. Gniazdowski, Konstytucja nowych Wegier - implikacje krajowe i regionalne, „Komentarze OSW” 2011, nr 60, za: http://www.osw.waw.pl/pl/publikacje/komentarzeosw/2011-07-29/konstytucja-nowych-wegier-implikacje-krajowe-i-regionalne (dostęp: 4 października 2011 r.). 
Konstytucja Wegier, został określony przez Europejską Komisję na Rzecz Demokracji przez Prawo (tzw. Komisja Wenecka) jako pospieszny, mało przejrzysty i pozbawiony warunków do debaty publicznej ${ }^{61}$.

\section{Zakończenie}

Wraz z restytucją instytucji głowy państwa pojawił się istotny problem dotyczący sposobu jej elekcji. Problem ten, postrzegany początkowo w kontekście pojawienia się nowych instytucji w systemie naczelnych organów władzy, w większości przypadków rozstrzygany był tak, aby podkreślać ich demokratyczny charakter, co miało determinujący wpływ na wybór w większości przypadków bezpośredniego trybu wyłaniania głowy państwa. W przypadku (zwłaszcza bezpośrednich) wyborów prezydenckich okazało się, iż wzbudzają one duże emocje społeczne, co przede wszystkim należy uzasadnić faktem, iż ich ostateczny wynik decyduje o obsadzie stanowiska państwowego, z którym związany jest największy prestiż. Z perspektywy ostatniego dwudziestolecia wydaje się, iż możliwość zastąpienia w przypadku analizowanych państw bezpośrednich wyborów głowy państwa wyborami pośrednimi jest mało realna. Należy również uznać, iż podjęcie takiej właśnie decyzji odbiegałoby od kierunku dotychczas wprowadzanych zmian. Niezależnie od pojawiających się w tej materii propozycji, za utrzymaniem dotychczasowego trybu optują tak sami politycy, jak i wyborcy, którzy raczej nie byliby gotowi z niego zrezygnować. Inaczej problem ten przedstawia się w przypadku państw utrzymujących pośredni tryb elekcji. W przypadku Republiki Czeskiej może się okazać, iż wprowadzenie wyborów bezpośrednich, jeżeli to w ogóle jest realne, będzie możliwe dopiero w bliżej nieokreślonej przyszłości, mimo iż oczekuje tego licząca się część elektoratu. Można ten problem ująć jeszcze inaczej, a mianowicie: o ile bezpośredni tryb wyłaniania prezydenta w państwach, gdzie jest on stosowany, cieszy się z takich czy innych powodów poparciem polityków i znacznej części wyborców, o tyle tryb pośredni, np. w Republice Czeskiej oraz jeszcze w Republice Węgierskiej, uznawany jest za optymalny wyłącznie przez samych polityków. Z założenia powinno to skłaniać do głębszych przemyśleń.

Pozostając jeszcze przy problemie wyboru prezydenta w wyborach pośrednich, a dokładnie rzecz biorąc, przy zaletach tego trybu wyłaniania głowy państwa, warto przytoczyć opinię przedstawioną na ten temat przez P. Winczorka. Jego zdaniem

61 Zob. European Commission for Democracy through Law, Opinion on the new Constitution of Hungary, za: http://www.venice.coe.int/docs/2011/CDL-AD\%282011\%29016-e.pdf (dostęp: 4 października 2011 r.). 
„[...] ostra kampania poprzedzająca wybory prezydenckie, która toczy się zwykle przez wiele miesięcy, przyczynia się - ze szkodą dla naprawdę ważnych spraw państwa - do chorobliwego rozedrgania całej krajowej sceny politycznej. Zjawisko to dostarcza [...] niemiłych doświadczeń [...]"62. Wprawdzie wypowiedź ta dotyczyła potencjalnej możliwości wprowadzenia pośrednich wyborów prezydenckich w Rzeczypospolitej Polskiej, warto jednak zastanowić się nad tą kwestią, także w odniesieniu do innych państw naszej części kontynentu europejskiego. Przede wszystkim należy zauważyć, że w przypadku państw praktykujących pośredni tryb elekcji głowy państwa kampania wyborcza może wydawać się bardziej „łagodna”. Jednak $\mathrm{z}$ drugiej strony należy postawić pytanie, czy aby np. w Republice Czeskiej czy Republice Węgierskiej mieliśmy do czynienia z rzeczywistą kampanią wyborczą. Bardzo wiele wskazuje na to, iż wyłanianie w tych państwach prezydenta stawało się tylko i wyłącznie wewnętrzną sprawą deputowanych, którzy bardzo rzadko czuli się zobowiązani do uwzględniania woli swoich wyborców. Przypuszcza się, że prowadzone kampanie wyborcze mogą negatywnie oddziaływać na postawy i poglądy obywateli. Jeżeli przyjmiemy taki punkt widzenia, wówczas rodzi się inne pytanie, a mianowicie: czy kampanie prowadzone w związku z wyborami prezydenckimi są bardziej "demoralizujące" niż te, które towarzyszą wyborom parlamentarnym czy samorządowym. Wydaje się, iż rzecz nie polega na tym, aby odgórnie „chronić” obywateli przed negatywnymi następstwami kampanii wyborczych. Nie można tego uczynić, tak samo jak nie można w sposób całkowity wyeliminować z życia politycznego różnego rodzaju patologii, których skutki w jeszcze większym stopniu zniechęcają obywateli do czynnego uczestnictwa w życiu społeczno-politycznym państwa.

\section{Differences and modifications of the method of presidential elections method in selected countries of Central, Eastern and Southern Europe}

The institution of president as a head of state has been a permanent feature in the countries of Central, Eastern and Southern Europe for more than twenty years. This fact does not mean that the institution of a head of state has become static and non-evolving. On the contrary, it has changed substantially. These changes are particularly visible in countries that have gone through system change. During therestitution of presidency the expectation of the society and the political class towards the head of state varied and were accompanied by serious political and law problems. One of most important of them was the method of presidential election.

62 Zob. P. Winczorek, Wybór prezydenta w innych rękach, „Rzeczpospolita” 2009, 22 października. 
Most of the states analyzed have decided to introduce direct presidential elections to stress the democratic nature of that institution. That decision was coherent with the expectations of the societies. The other method of presidential elections, that is indirect elections, was introduced in the Czech Republic and Hungary, and from the beginning it has been considered satisfying, particularly by the politicians. What is more important, particularly in all the analyzed countries of Central, Eastern and Southern Europe which introduced indirect presidential elections, that method is still evolving. The aim of that evolution is enhancement of the method, and enhancement accompanies the process of evolution and modernization of the institution of head of state.

\section{Les différences et les modifications du mode d'élection du président dans certains pays d'Europe centrale, orientale et méridionale}

Depuis plus de vingt ans, l'institution du président est l'organe suprême du pouvoir, qui fonctionne en permanence dans les pays d'Europe centrale, orientale et méridionale. Cela ne signifie pas que le chef d'État est devenu une institution statique et immuable. Au contraire, il subit des changements significatifs, ce qui est particulièrement évident dans le cas des pays qui ont connu un processus de transformation politique. La restauration de la fonction de président a été liée non seulement à des attentes différentes de la société et des politiciens envers ce nouvel organe suprême du pouvoir, mais aussi à des questions juridiques et politiques significatives. L'une des plus importantes d'entre elles était le mode délection du président.

Dans la plupart des pays étudiés, le mode délection direct du chef d'État a été introduit afin de souligner le caractère démocratique de cette institution. En outre, cette décision sest avérée répondre aux attentes sociales. Le mode délection indirect, adopté en République tchèque et en République hongroise, depuis son introduction jusquà aujourd'hui, semble être satisfaisant en particulier pour les politiciens. Il est important que dans tous les pays analysés d'Europe centrale, orientale et méridionale, qui ont adopté le mode d'élection direct, ce mode continue à subir des changements, qui visent à l'améliorer. Cela fait clairement référence au processus de lévolution et de la modernisation de l'institution du chef d'État. 